\title{
THE INCLUSIVENESS OF EUROPEAN DECISION RULES
}

\author{
Thomas König and Thomas Bräuninger
}

\begin{abstract}
European Union Member States increasingly draw attention to the choice between and within various decision rules. Two prominent approaches, relative voting power studies and spatial models, assess the choice within the standard, cooperation, and co-decision procedures. However, they cannot sufficiently explain the Member States' choice of these rules. In this article, we present our model on absolute inclusiveness and relative decisiveness referring to two aspects of Member States' choice: their absolute chances to be incorporated in collective decision-making and their relative chances to be decisive actors thereby. We argue that the combination of both power aspects gives insight into the choice of rules, and we apply both indices to the actual power distributions in the Council of Members.
\end{abstract}

KEY WORDS • absolute inclusiveness • decision rules • European Union

- game theory $\bullet$ power

\section{European Decision-making in Transition}

European Union (EU) Member States are attracting increasing attention in their choice and use of majority voting rules. Despite the formal majority provisions of the Rome Treaties (1958), the Luxembourg Accords (1966) often called an intergovernmental agreement to disagree - granted all Member States veto power up to the mid-1980s (Kapteyn and Verloren van Themaat, 1990: 249). ${ }^{1}$ In 1986 the Council of Ministers (CM) stated in the Official Journal that 40 legislative proposals had been adopted by qualified majority - tripling the total figure for 1985 (WQ 1121/86, C306/42). By the end of 1986, the CM had increased the total figure to more than 100 qualified majority decisions, and on single-market issues in particular (Nugent, 1994: 147). Qualified majority decision-making may facilitate EU policy change, but the Member States' remarkable use of qualified majority

A program able to calculate different voting power indices for simple games in single- and multi-chamber systems with unweighted and weighted votes of actors is available from the authors at <http://www.mzes.uni-mannheim.de/arb2/pow.html>

1. For an overview of the formal Treaty provisions and their modifications by Treaty reforms, see König (1996). 
voting begs the question as to why they should have given up consensual EU legislation.

Unlike unanimity, weaker majority rules jeopardize the inclusion of a Member State's policy position in EU legislation, implying that Member States bargain on a strategy of policy-seeking for the regulation of potential EU legislation (Garrett et al., 1995: 566). The problem in conducting an analysis of the Member States' choice of CM decision rules lies in measuring Member States' policy-seeking strategies on institutional choice, since the location of preferences in spatial terms is uncertain (Buchanan and Tullock, 1962: 78). When Member States make their choice of CM decision rules they are not provided with precise information on the exact amount of potential legislative proposals, nor on their concrete policy positions which may favour or hinder coalition-building. To paraphrase Tsebelis (1990: 98), '[since] the expected life of institutions is much higher than the expected life of policies ... the transition from preferences over policies to preferences over institutions is neither automatic nor straightforward'. Accordingly, many analyses on institutional choice are concerned with the calculation problem of how to measure the consequences of decision rules.

In this article we present our concept of absolute inclusiveness showing the Member States' individual chances of being incorporated in potential legislative decision-making. It is an absolute policy-seeking concept in the sense that the value of each Member State ranks between its potential exclusion from, and its necessary inclusion in all feasible CM winning coalitions. In the case of its potential exclusion, the Member State has a dummy player position in the CM. By contrast, a Member State is a vetoplayer if it cannot be excluded from any $\mathrm{CM}$ winning coalition. Compared to other voting power indices of actors' relative decisiveness, our inclusiveness index allows us to measure the absolute power aspect of decision rules on legislative decision-making at both the individual and systemic level. We argue that our inclusiveness concept uncovers a second dimension of the Member States' choice of decision rules, referring to the trade-off between the individual aspect of being included in potential EU legislation and the systemic aspect of the potential for policy change.

The remainder of this article provides an introduction to the discussion on the institutional delegation of decision rules by the Member States. It shows that neither the relative voting power nor the spatial model approach can sufficiently explain the Member States' choice of EU decision rules. We present our model on absolute inclusiveness and relative decisiveness. We argue that both power aspects have to be taken into account when we deal with Member States' choice of decision rules. Finally, we apply both indices to the actual decision rules in the CM. Compared to unanimity, our findings show that large Member States gain 
most relative power and lose the lowest amount of absolute power under weighted qualified majority voting. With regard to relative power, smaller Member States preserve their power share in cases of unweighted simple majority voting, while also having the lowest absolute power losses under double majority voting.

\section{The Intergovernmental Approach to Expected Legislative Gains}

Two particular events were important for the Member States' transition to qualified majority voting in the CM: first, the Member States' intention to adopt 282 measures for completing the internal market that they documented in the White Paper (1985); second, the so-called 'southern enlargement' with the accession of Greece in 1981 and of Spain and Portugal in 1986 increasing socio-economic variation among Member States. Most Member States were convinced of the need to increase the potential for EU policy change by relaxing the strong decision rule of unanimity in the CM. In 1987, the Member States confirmed their approval of EU policy change by passing the Single European Act (SEA). Although the SEA was indeed ratified, the Member States nevertheless differed in their preferences on the choice of CM decision rules for potential EU legislation.

From an intergovernmental perspective, Garrett (1992: 546) reports that on the SEA negotiations a southern coalition and Ireland preferred resorting to simple majority rule in the $\mathrm{CM}$, while the United Kingdom and Denmark favoured continuing with unanimity rule. As it turned out, the third alternative supported by the founding members, Germany, France and the Benelux countries, succeeded when qualified majority voting came into force with respect to internal market legislation. A similar configuration on the choice of CM decision rules was to be found when Austria, Finland and Sweden joined the European Union in 1995. As they are relatively small and belong to the group of richer EU countries, their accession shifted the equilibrium both between larger and smaller Member States and between northern and southern Member States (Hosli, 1996: 260). Since all Member State governments have to agree consensually on treaty reforms, we will turn our attention to the intergovernmental perspective in order to discover the particular reasons for the Member States' choice of CM decision rules.

The institutional delegation or choice of decision rules is the last step in the intergovernmental approach to EU Treaty negotiations. The stepwise approach starts with the analysis of national policy formation in the Member States, then studies interstate bargains that finally lead to institutional delegation. Applied to the development of the original European Economic Community, the institutional delegation of qualified majority 
decision rule results from the corresponding economic policy positions of the Member State governments and their relative power relationship during the SEA negotiations (Moravcsik, 1991: 50; Lange, 1993: 5; Garrett, 1993: 105). At first glance, the success of those Member States favouring qualified majority seems predictable for many reasons. The FrancoGerman coalition had been the driving force of EU integration in the past (Wallace, 1985; Moravcsik, 1991, 1993). Moreover, this group favoured the intermediate position between unanimity and simple majority that was also the median. ${ }^{2}$ On closer inspection, however, the actual provisions for qualified majority voting also differ with regard to Member States' allocated voting weights: in contrast to the equal settings for unanimity and simple majority, qualified majority distinguishes between larger and smaller Member States. ${ }^{3}$

Accordingly, there are two dimensions for Member States' choice of CM decision rules: on the one hand, the Member States determine the potential for EU policy change when they decide between strong and weak CM decision rules. Weaker majority rules may increase the potential for EU policy change, if the feasible exclusion of some Member States will raise the winset of the status quo. ${ }^{4}$ On the other hand, they distinguish among themselves when they establish equal or unequal settings by introducing different voting weights. Since Member States are all equal under unanimity, the crucial question is why smaller Member States accept the higher voting weights of larger Member States. If the signatories are rational actors, one must explain the reasons for both the principle of (in-)equality and the strength of CM decision rules.

The inequality of Member States has often been measured by applying different voting power indices (Brams, 1975; Brams and Affuso, 1985; Hosli, 1993; Widgrén, 1994; Johnston, 1995; Lane et al., 1995; Brückner and Peters, 1996). Here, most power indices analyse the CM power distribution by means of the Member States' relative ability to be decisive in forming $\mathrm{CM}$ winning coalitions. Leaving the problem of selecting the appropriate voting power index aside, their results can be both enlightening yet at the same time partial. Enlightening, because they indicate the Member States' relative chances of being influential in potential EU legislation. Partial,

2. Using Black's theorem (1958) for majority decision-making, many forecasting models of international bargains make their predictions of single-dimension issues on the basis of the median (e.g. Bueno de Mesquita et al., 1996).

3. The voting weights are approximately related to the size of the Member States' population although France and Germany initially preferred a weighting according to their economic power (Garrett, 1992: 546).

4. The winset of the status quo consists of all feasible alternatives which change the status quo (Shepsle and Weingast, 1987: 90). The size of the winset is determined by the set of winning coalitions and the distances of their actors' policy positions to the status quo. 
because the relative power concept does not take into account the important distinction between strong and weak decision rules (Dowding, 1991: 59).

Recent CM voting power analyses have systematically disregarded the strength of decision rules in cases of equal settings, when developing their relative concept of Member States' decisiveness. In fact, Member States have the same relative voting power share in cases of unanimous and unweighted majority voting. As a result, CM voting power analysis has been fundamentally called into question by the argument that it ignores the policy positions of the Member States and their inter-institutional interaction with supranational actors in EU legislation, particularly in the cooperation and co-decision procedure (Garrett and Tsebelis, 1996: 270). Concerning inter-institutional interaction, both standard power indices and power indices with policy preferences may generate extremely misleading conclusions (Tsebelis and Garrett, 1996).

In view of the legislative inter-institutional interaction with supranational actors, spatial analyses have demonstrated that the European Parliament has a conditional agenda-setter position in the cooperation procedure (Tsebelis, 1994, 1996) and conditional blocking power in the codecision procedure (Schneider, 1995). An additional aspect is that the Commission has the sole right to initiate EU legislation. Assuming extreme policy positions of the European Parliament and/or the Commission, spatial analyses outline the decrease of the Member States' potential for policy change. ${ }^{5}$ Although supranational actors have prominent functions in EU legislation, we relax the assumption on extreme policy positions of both supranational actors for our explanation of the Member States' choice of CM decision rules. ${ }^{6}$ Consequently, we argue that the Member States' policy-seeking strategy is determined less by inter-institutional interaction than by the (un-)equal and strong arrangements which regulate their own coalition-building problem.

There are two important reasons for Member States focusing on their own coalition-building problem in the CM when they introduce or modify

5. Compared to the standard procedure, the size of the winset of the status quo decreases if in the cooperation and co-decision procedure the additional legislative actor has extreme policy positions and either agenda-setting or veto power.

6. For choices within EU decision rules it cannot be ruled out that supranational actors actually have extreme policy positions limiting the Member States' potential for EU policy change. When the Member States make their choice of EU decision rules, however, they are not provided with precise information on their concrete policy positions. For the choice of EU decision rules the assumption on extreme policy positions of supranational actors thus generates the question as to why Member States establish their participation in EU legislation.

7. For an overview on the inter-institutional distribution of absolute and relative power, see König (1997) and König and Bräuninger (1997). 
decision rules. First, Member States do not know the spatial location of the Parliament's and the Commission's policy positions for potential EU legislation. The participation of supranational actors rather refers to the Member States' willingness to reduce legislative transaction costs, in particular agenda-setting costs and legitimization costs for EU legislation. ${ }^{8}$ Second, the comparison of the procedural set of winning coalitions containing all sets of actors able to adopt a legislative proposal reveals that the sets of the cooperation and co-decision procedures only differ with respect to the rather small subset of coalitions including the unanimous CM. ${ }^{9}$ Since intergovernmental unanimity guarantees that all Member States' policy positions are included, we assume that inter-institutional interaction is not crucial for the Member States' choice of CM decision rules.

We note that recent $\mathrm{CM}$ voting power analyses ignored the Member States' policy-seeking strategy when they focused on the decisiveness of Member States. Another aspect must also be considered, namely, that Member States established voting weights when they agreed on qualified majority voting. Under unanimity, all Member States have a veto-player position, but voting weights introduce prerogatives for larger Member States. Both the risk of exclusion and the distinction between the Member States regarding their voting weights beg the question as to the Member States' expectations for potential EU legislation. If the signatories are rational, any explanation of the choice of rules must take into account the Member States' expectations for potential collective decision-making within those rules.

\section{The Relative and Absolute Aspects of the Choice of Rules}

Our explanation of the Member States' choice of CM decision rules starts with the assumption that all Member States should expect legislative gains from potential EU legislation. Member States have no benefits from constitutional provisions but from legislative policy-making structured by

8. The Commission's agenda-setting function ensures the continuous supranational character of EU legislation, while the European Parliament's participation may further lower the acceptance of EU decision-making, the so-called democratic deficit of EU legislation (Ludlow, 1991). The transaction-cost argument can also be applied to the European Court of Justice.

9. In fact, the procedures offer a second subset to the procedural set of winning coalitions. In both procedures, the first subset consists of all coalitions including the Commission, at least the qualified majority of the Member States and at least the simple majority of the Parliament. The second subset in the cooperation procedure is determined by all coalitions consisting of the Commission and the unanimous Member States, whereas the second subset in the codecision procedure is defined by all coalitions with unanimous Member States and at least a simple majority of the Parliament (König, 1997: 69). 
constitutional provisions. Subsequently, their choice of EU decision rules presupposes the comparison of probable outcomes under different rules. Since the signatories have to adopt all EU Treaty reforms consensually, any transition of $\mathrm{CM}$ decision rules has to fulfil an efficiency criterion. We suppose that any change depends on higher expected benefits than expected costs, and that these expected net gains must be higher than those of current rules. Given these preconditions, the question of institutional delegation is, then, which point along the Pareto frontier the signatories will choose (Krasner, 1991: 340).

We argue that the choice of strong or weak decision rules reveals the Member States' expectations for the potential of EU policy change. If the Member States expect legislative gains from increasing the potential of EU policy change, they have incentives to relax strong provisions lowering their absolute inclusiveness, otherwise the actual provision will prevail. Each Member State will therefore only risk the exclusion of its policy position if the increased potential of EU policy change promises legislative profits. With regard to absolute inclusiveness, the question is to what degree Member States contribute to an increased potential of policy change.

Concerning the choice of equal or unequal settings, the answer depends on the expected similarity of the Member States' legislative gains. In our view, the expectation of similar profits will favour 'One-Member-OneVote' provisions, while dissimilar profit expectations may be compensated by unequal settings. Our argument regarding fair distribution is based on economic competition within the internal market, since a permanent asymmetric distribution of legislative gains will shift the Member States' competition relationships. Therefore, larger Member States expect lower gains from opening their markets, due to their lower benefits or higher costs. Larger Member States are compensated with higher voting weights which establish prerogatives in CM decision-making. However, before applying any efficiency criterion on the Member States' choice of decision rules, we must solve the problem of how to measure the individual and systemic consequences of decision rules.

In order to operationalize the Member States' choice of CM decision rules we reduce our argument to two aspects of expected legislative gains. We model both aspects using the concept of simple games with two inherent properties: first, they differentiate between winning and losing coalitions; and second, they satisfy monotonicity (Shapley, 1962: 59). Both properties are consistent with CM decision-making. Since CM decisionmaking operates with Yes- and No-votes, we are able to distinguish between winning and losing coalitions. Additionally, monotonicity can be assumed because a winning coalition is not endangered by the accession of an additional Member State. 


\section{Absolute Inclusiveness}

The starting point of a simple game is a finite set of players that can be interpreted as decision-making units. In the case of equiprobable Yes- and No-alternatives, a Member State's probability of being included in a collective decision varies between 0.5 and 1.0 with respect to the decision rule. A Member State is a veto-player with the maximal inclusiveness of 1.0 if it cannot be excluded from any feasible winning coalition. In the case of unanimity, any Member State is a veto-player. By contrast, if a Member State can be excluded from any feasible winning coalition, the inclusion of its policy position is determined by luck (Barry, 1989: 287). Thus, the inclusiveness of this dummy player is still 0.5 , since Yes- and No-votes are equiprobable. $^{10}$

If a Member State is neither a veto-player nor a dummy player we calculate its absolute inclusiveness according to the relationship between its frequency of participation in winning coalitions and all feasible winning coalitions. Formally, we assume that all Yes- and No-votes are equiprobable in the CM voting game $v$ over the set $N$ of all $n$ Member States. We define the inclusiveness $\omega_{i}$ of a Member State $i$ as its frequency of participation in winning coalitions that is related to the number of all feasible winning coalitions (Bräuninger, 1996: 42):

$$
\omega_{i}(v)=\frac{\sum_{S \subseteq N, i \in S} v(S)}{\sum_{S \subseteq N} v(S)}
$$

where $v(S)=1$ if $S$ is winning, and $v(S)=0$ if $S$ is losing.

In contrast to relative voting power indices, our concept is not based on the Member States' relative decisiveness but on the absolute inclusiveness of policy positions. The difference between our absolute inclusiveness and other voting power indices becomes obvious when we consider the systemic consequences of decision rules. On the systemic level, inclusiveness expresses how many winning coalitions exist in relation to all feasible coalitions (Coleman, 1971: 278). Without having knowledge of the preferences of actors, the decision probability is:

10. There are two prominent indices which are related to the absolute positions of actors in simple games, the non-normalized or absolute Banzhaf (1965) and the Rae (1969) index. However, the non-normalized Banzhaf index measures the 'absolute decisiveness' of actors but not their absolute inclusiveness: it relates the actors' decisive contributions in forming winning coalitions to the absolute number of all feasible swings. The range of the nonnormalized Banzhaf index therefore not only depends on the strength of decision rules but also on the number of actors. The Rae index purely measures the actors' satisfaction in terms of their congruence in Yes- and No-votes but it disregards the systemic impact of decision rules on the potential for policy change. 


$$
P(v)=\frac{\sum_{S \subseteq N} v(S)}{2^{n}} .
$$

We first illustrate our concept in Table 1 before analysing the more complex procedural settings for EU legislation. Each cell (counterclockwise from top left) contains the derivations of the actors' values for their absolute inclusiveness and their relative decisiveness. The first example of unanimity refers to a set of four Member States consisting of three actors $\mathrm{X}$ and one actor $\mathrm{O}$. The maximal inclusiveness $\omega_{O}=1$ for actor $\mathrm{O}$ is guaranteed because he must collaborate with the other three actors $\mathrm{X}$ in order to change the legislative status quo. This also holds true for the inclusiveness $\omega_{X}$ of any actor $X$. While the individual inclusiveness of all actors is very high, the systemic decision probability $P$ is reduced to that of the single favourable winning coalition of all 16 feasible coalitions, namely, 0.0625 .

In the second example of simple majority rule, actor $\mathrm{O}$ is included in three winning coalitions containing two actors $\mathrm{X}$ and in the grand coalition of all actors. Actor $\mathrm{O}$ can only be excluded from the single winning coalition consisting of all three actors X. Since five winning coalitions are possible and all actors are equal, each actor is included in four out of five

Table 1. Legislature with Four Actors and Four Decision Rules

\begin{tabular}{|c|c|c|c|}
\hline \multicolumn{2}{|c|}{ 1. Unanimity Rule } & \multicolumn{2}{|c|}{ 4. Majority Voting with Veto-player ${ }^{(c)}$} \\
\hline $\begin{array}{l}\text { Winning Coalitions } \\
\{\mathrm{O}, \mathrm{X}, \mathrm{X}, \mathrm{X}\}(1 \times)\end{array}$ & $\begin{array}{l}\text { Voting Sequences } \\
\text { OXXX* } \quad(6 \times) \\
\text {XOXX* }^{*}(6 \times) \\
\text {XXOX* }^{*}(6 \times) \\
\text {XXXO* }^{*}(6 \times) \\
\phi_{O}=\frac{1}{4} \\
\phi_{X}=\frac{1}{4}\end{array}$ & $\begin{array}{ll}\text { Winning Coalitions } \\
\{\mathrm{O}, \mathrm{X}, \mathrm{X}\} & (3 \times) \\
\{\mathrm{O}, \mathrm{X}, \mathrm{X}, \mathrm{X}\} & (1 \times)\end{array}$ & $\begin{array}{l}\text { Voting Sequences } \\
\text { OXX*X } \quad(6 \times) \\
\mathrm{XOX}^{*} \mathrm{X} \quad(6 \times) \\
\mathrm{XXO}^{*} \mathrm{X} \quad(6 \times) \\
\mathrm{XXXO}^{*} \quad(6 \times) \\
\phi_{O}=\frac{1}{2} \\
\phi_{X}=\frac{1}{6}\end{array}$ \\
\hline \multicolumn{2}{|c|}{ 2. Majority Voting ${ }^{(a)}$} & \multicolumn{2}{|c|}{ 3. Majority Voting with Weighted Votes ${ }^{(b)}$} \\
\hline $\begin{array}{ll}\text { Winning } & \text { Coalitions } \\
\{\mathrm{O}, \mathrm{X}, \mathrm{X}\} & (3 \times) \\
\{\mathrm{X}, \mathrm{X}, \mathrm{X}\} & (1 \times) \\
\{\mathrm{O}, \mathrm{X}, \mathrm{X}, \mathrm{X}\} & (1 \times) \\
& \\
\omega_{O}=\frac{4}{5} & \\
\omega_{X}=\frac{4}{5} & \\
P=\frac{5}{16} & \end{array}$ & 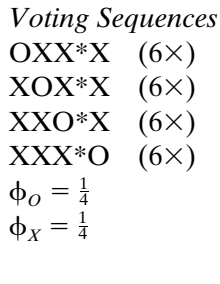 & $\begin{array}{ll}\text { Winning } & \text { Coalitions } \\
\{\mathrm{O}, \mathrm{X}\} & (3 \times) \\
\{\mathrm{O}, \mathrm{X}, \mathrm{X}\} & (3 \times) \\
\{\mathrm{X}, \mathrm{X}, \mathrm{X}\} & (1 \times) \\
\{\mathrm{O}, \mathrm{X}, \mathrm{X}, \mathrm{X}\} & (1 \times) \\
\omega_{O}=\frac{7}{8} & \\
\omega_{X}=\frac{5}{8} & \\
P=\frac{8}{16} & \end{array}$ & $\begin{array}{l}\text { Voting Sequences } \\
\text { OX*XX } \quad(6 \times) \\
\text { XO*XX } \quad(6 \times) \\
\text { XXO*X } \quad(6 \times) \\
\text { XXX*O } \quad(6 \times) \\
\phi_{O}=\frac{1}{2} \\
\phi_{X}=\frac{1}{6}\end{array}$ \\
\hline
\end{tabular}

(a) actors $\mathrm{X}$ and $\mathrm{O}$ one vote each; $3 / 4$ majority rule

(b) actors $\mathrm{X}$ one vote each, actor $\mathrm{O}$ two votes; $3 / 5$ majority rule

(c) actors $\mathrm{X}$ and $\mathrm{O}$ one vote each, $\mathrm{O}$ veto-player; $3 / 4$ majority rule 
feasible winning coalitions. This increases the decision probability $P$ to 0.3125 . The two examples show how strong and weak decision rules contrarily affect the absolute inclusiveness of equal actors' policy positions and the potential for policy change.

Our third example introduces different voting weights. We provide actor $\mathrm{O}$ with two votes, whereas the other three actors $\mathrm{X}$ have only one vote. Thus, actor $\mathrm{O}$ is member of seven out of eight feasible winning coalitions, while all actors $\mathrm{X}$ are included in only five winning coalitions. The higher number of winning coalitions also increases the decision probability $P$ to 0.5 . Finally, we introduce a single veto-player. Actor $\mathrm{O}$ has to be included in all winning coalitions, but one actor $\mathrm{X}$ can be excluded from the formation of a winning coalition at any one time. As a result, the inclusiveness of actor $\mathrm{O}$ is 1.0, whereas each actor $\mathrm{X}$ can be excluded from one out of four feasible winning coalitions. Since the number of winning coalitions is reduced, the potential for policy change decreases to 0.25 . These examples point out how unequal settings determine the absolute inclusiveness at the individual and systemic level.

\section{Relative Decisiveness}

The second aspect of the Member States' choice of rules can be measured by the relative decisiveness concept of voting power indices. Despite their different features, the increasing number of relative voting power indices is becoming more of a burden than a blessing. Brückner and Peters (1996) calculate the relative power distribution in the CM using different voting power indices, though they refer to the important distinction between the relative power of Member States to be decisive and the Member States' absolute power to make or to block collective decisions. They emphasize the difference between the 50 percent simple, and the 70 percent qualified majority rule, 'even if the Banzhaf scores are very similar' (Brückner and Peters, 1996: 419).

Hosli (1996: 269) argues that the relative voting power of Member States is likely to be one of the most crucial factors in determining policy outcomes. In most cases, we would recommend applying the ShapleyShubik index (1954) as it is the most appropriate measure for the voting power distribution in multi-chamber systems ${ }^{11}$ (König and Bräuninger, 1996: 338). Let $v$ be the simple CM voting game over the set of Member

11. In contrast to single-chamber systems, multi-chamber systems are characterized by twostep decision-making. In the first step of the subgame level, the actors have to solve their internal coalition problem under different conditions when either the size of the chambers or their decision rules differ (Shelley, 1986: 260). In the second step of the compound level, the results of the subgames are connected in the collective decision. Regarding the distribution of relative voting power, the Shapley-Shubik index does not privilege chambers with highly vulnerable coalitions (Straffin, 1977: 109). 
States $N$, then the relative decisiveness $\phi_{i}$ of a Member State $i$ according to Shapley and Shubik is

$$
\phi_{i}(v)=\sum_{S \subseteq N} \frac{(s-1) !(n-s) !}{n !}[v(S)-v(\mathrm{~S} \backslash\{i\})]
$$

where $n$ and $s$ are the cardinal numbers of $N$ and $S$ respectively.

Table 1 points out the limitations of relative power analyses in explaining the choice of strong and weak rules. The second column of each cell shows the derivation of the relative voting power shares. In all four examples, 24 voting sequences exist for the four actors, but the decisive positions indicated by the star are occupied by exactly the same actors. The actors thus have the same relative voting power in both cases of either strong or weak rules. Relative power analyses therefore cannot explain the choice between strong and weak decision rules.

Unequal settings, however, affect the relative power distribution among the Member States. If actor $\mathrm{O}$ is privileged with either two votes or a vetoplayer position, it is decisive in 12 of all 24 voting sequences. While actor $\mathrm{O}$ receives half of the relative voting power, the other actors $\mathrm{X}$ share the remaining voting power. Since actor O's voting power is three times higher than the voting power of any actor $\mathrm{X}$, all actors expect actor $\mathrm{O}$ to have a minor payoff - as long as our assumption on a fair distribution is correct. Consequently, all actors concede to balance the expected unequal distribution by introducing unequal chances of being decisive.

Table 2. Characterization of Decision Rules

\begin{tabular}{|c|c|c|c|}
\hline \multirow{3}{*}{\multicolumn{2}{|c|}{ high }} & \multicolumn{2}{|c|}{ Decisiveness of actors } \\
\hline & & equal & unequal \\
\hline & & $\begin{array}{c}\text { unanimity } \\
\text { (veto rights } \\
\text { for all actors) }\end{array}$ & $\begin{array}{l}\text { veto right } \\
\text { for single } \\
\text { actor }\end{array}$ \\
\hline $\begin{array}{l}\text { Inclusiveness } \\
\text { of an actor }\end{array}$ & low & $\begin{array}{l}\text { unweighted } \\
\text { majority } \\
\text { voting }\end{array}$ & $\begin{array}{c}\text { weighted } \\
\text { majority } \\
\text { voting }\end{array}$ \\
\hline
\end{tabular}

These examples illustrate the two properties of decision rules that are important for the Member States' choice. To sum up, lowering the decision-making criterion reduces absolute inclusiveness and in addition, different voting weights may distinguish between Member States. Table 2 combines both aspects of decision rules with regard to institutional delegation. If individual inclusiveness is intended to be high and the legislative gains of the Member States are expected to be similar, unan- 
Table 3. Voting Power and Inclusiveness in EU Council Decision-making Procedures

\begin{tabular}{|c|c|c|c|c|c|c|c|c|c|c|c|}
\hline \multirow{2}{*}{$\begin{array}{l}\text { Member } \\
\text { State }\end{array}$} & \multirow{2}{*}{$\begin{array}{l}\text { Voting } \\
\text { Weight }\end{array}$} & \multicolumn{2}{|c|}{$\begin{array}{c}\text { Unweighted } \\
\text { Simple Majority }\end{array}$} & \multicolumn{2}{|c|}{ Simple Majority } & \multicolumn{2}{|c|}{ Qualified Majority } & \multicolumn{2}{|c|}{$\begin{array}{c}\text { Double } \\
\text { Qualified Majority }\end{array}$} & \multicolumn{2}{|c|}{ Unanimity } \\
\hline & & $\phi$ & $\omega$ & $\phi$ & $\omega$ & $\phi$ & $\omega$ & $\phi$ & $\omega$ & $\phi$ & $\omega$ \\
\hline Germany & 10 & 0.0667 & 0.6047 & 0.1183 & 0.6630 & 0.1167 & 0.8627 & 0.1114 & 0.8490 & 0.0667 & 1.0000 \\
\hline Italy & 10 & 0.0667 & 0.6047 & 0.1183 & 0.6630 & 0.1167 & 0.8627 & 0.1114 & 0.8490 & 0.0667 & 1.0000 \\
\hline UK & 10 & 0.0667 & 0.6047 & 0.1183 & 0.6630 & 0.1167 & 0.8627 & 0.1114 & 0.8490 & 0.0667 & 1.0000 \\
\hline Spain & 8 & 0.0667 & 0.6047 & 0.0917 & 0.6271 & 0.0955 & 0.8003 & 0.0920 & 0.7939 & 0.0667 & 1.0000 \\
\hline Belgium & 5 & 0.0667 & 0.6047 & 0.0556 & 0.5781 & 0.0552 & 0.6909 & 0.0563 & 0.7098 & 0.0667 & 1.0000 \\
\hline Greece & 5 & 0.0667 & 0.6047 & 0.0556 & 0.5781 & 0.0552 & 0.6909 & 0.0563 & 0.7098 & 0.0667 & 1.0000 \\
\hline Netherlands & 5 & 0.0667 & 0.6047 & 0.0556 & 0.5781 & 0.0552 & 0.6909 & 0.0563 & 0.7098 & 0.0667 & 1.0000 \\
\hline Portugal & 5 & 0.0667 & 0.6047 & 0.0556 & 0.5781 & 0.0552 & 0.6909 & 0.0563 & 0.7098 & 0.0667 & 1.0000 \\
\hline Austria & 4 & 0.0667 & 0.6047 & 0.0464 & 0.5651 & 0.0454 & 0.6556 & 0.0476 & 0.6798 & 0.0667 & 1.0000 \\
\hline Sweden & 4 & 0.0667 & 0.6047 & 0.0464 & 0.0561 & 0.0454 & 0.6556 & 0.0476 & 0.6798 & 0.0667 & 1.0000 \\
\hline Denmark & 3 & 0.0667 & 0.6047 & 0.0326 & 0.5462 & 0.0353 & 0.6167 & 0.0389 & 0.6486 & 0.0667 & 1.0000 \\
\hline Finland & 3 & 0.0667 & 0.6047 & 0.0326 & 0.5462 & 0.0353 & 0.6167 & 0.0389 & 0.6486 & 0.0667 & 1.0000 \\
\hline Luxembourg & 2 & 0.0667 & 0.6047 & 0.0218 & 0.5306 & 0.0207 & 0.5736 & 0.0251 & 0.6069 & 0.0667 & 1.0000 \\
\hline
\end{tabular}


imous decision rules may come into force in the CM. High inclusiveness under dissimilar circumstances may result in particular veto-player positions for some Member States. Low inclusiveness comes along with majority rules in the $\mathrm{CM}$, but the 'One-Member-One-Vote' provision may be replaced by different voting weights in cases of dissimilar legislative gains. Thus, the combination of relative decisiveness and absolute inclusiveness reveals the reasons for the signatories' choice of decision rules. We now apply both concepts to the institutional delegation of $\mathrm{CM}$ decision rules.

\section{Member States' Absolute Inclusiveness and Relative Decisiveness}

The essentials of decision-making rules become obvious in our application to the actual CM consisting of 15 Member States. Except for the vetoplayer position of some particular Member States, CM decision rules vary according to the principle of (in-)equality and strength. In Table 3 relative voting power is measured by the Shapley-Shubik index $\phi$, and inclusiveness is determined by our index $\omega$. The procedural decision probability $P$ is indicated in the last row of Table 3. The analysis compares five decision rules: (i) unweighted simple majority with 8 out of 15 members; (ii) simple majority consisting of 44 out of 87 votes; (iii) qualified majority with 63 out of 87 votes; (iv) double qualified majority with the additional provision of a minimum of 10 members; and (v) unanimity of all 15 Member States.

Concerning the inclusiveness of Member States, unanimity and simple majority are the most dissimilar decision rules. The inclusiveness of the Member States varies between 1.00 and 0.60 , and decision probability ranges between 0.5 and 0.00003 . Relative decisiveness, however, does not distinguish between the strongest and the weakest rule. All Member States are provided with $1 / 15$ of relative voting power under both unanimity and simple majority. These findings support our argument that recent $\mathrm{CM}$ voting power analyses have systematically disregarded the crucial distinction between strong and weak CM decision-making.

Compared to simple unweighted majority, weighted votes may reduce the inclusiveness of particular Member States even further, yet preserve the decision probability. The actual distribution of voting weights provides larger Member States with 10 votes, while Luxembourg has two votes. From Luxembourg up to Spain, the inclusiveness of all smaller Member States decreases should the Member States introduce weighted simple majority. Whereas the smaller Member States' risk of exclusion slightly increases, the inclusiveness of larger members is raised from almost 60 percent to around 66 percent. However, the relative power distributions indicate a still more significant change upon the introduction of weighted 
simple majority rule. The larger Member States' relative decisiveness would be almost doubled, with smaller Member States having to pay for the larger Member States' relative prerogative.

Compared to weighted simple majority, qualified majority affects the inclusiveness more than the decisiveness of Member States. Again, larger Member States significantly decrease their risk of exclusion, whereas their relative decisiveness remains almost unchanged. However, compared to simple majority voting, the decision probability decreases from 0.5 to 0.0778 under qualified majority. Another finding concerns the double majority, often considered to restrict the larger Member States. Comparing qualified and double qualified majorities, the latter not only shifts relative power to the smaller states but also reduces the blocking ability of larger members. Thus, double majority improves the chances of smaller states of being included in a winning coalition and provides them with a higher amount of relative power. At the same time, the decision probability of 0.0778 remains almost unchanged.

Up to now, the Member States have sweepingly refrained from establishing simple majority rule because it is not expected to bring about equally shared EU legislative profits. The same holds true for weighted simple majority voting, which has not yet become a $\mathrm{CM}$ decision rule. The signatories did not agree on a highly asymmetric distribution of legislative gains benefiting smaller Member States. In the past, by contrast, Member States shifted from unanimous to qualified majority voting and thereby adopted a decision rule trying to balance the expected lower gains of larger Member States and the expected higher gains of smaller Member States from potential EU legislation.

\section{Shifting Larger and Smaller Member States' Relative and Absolute Power}

Our findings show that the distinction between relative power and absolute inclusiveness is not merely analytical. Concerning the institutional delegation of CM decision rules, both concepts outline different arguments for Member States' choice, which must be taken separately into account. Absolute inclusiveness refers to the potential of EU policy change because Member States will only risk their exclusion from potential legislation if they expect legislative gains. Relative decisiveness, however, builds on the distribution of legislative gains. Since a competitive EU internal market may produce dissimilar profits for the Member States' economies, the signatories privileged larger Member States by providing them with higher voting weights to rule out a continuous asymmetric distribution of legislative gains. 
Table 4. Power Effects by Transformation from Unanimity to Majority Voting

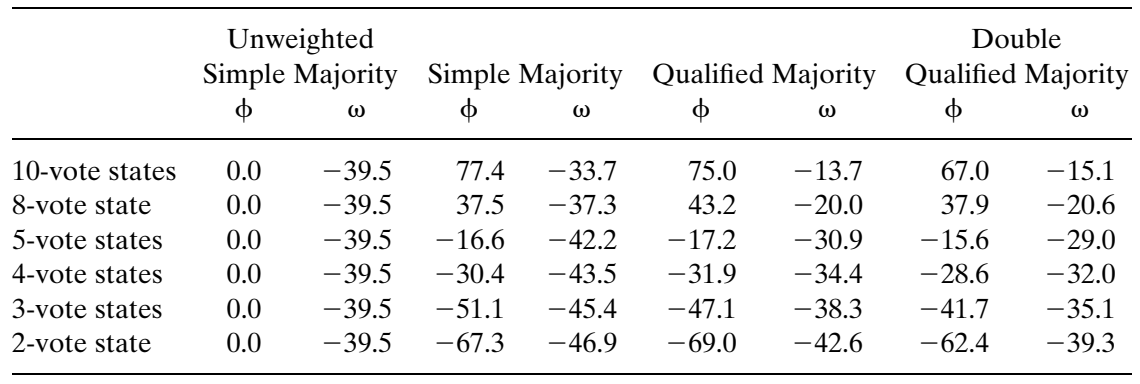

Note: For states, see Table 3.

Compared to unanimity, Table 4 lists the power effects by the transformation of unanimity to majority voting. Larger Member States not only receive the highest relative power share from the transition to qualified majority voting but they also have the lowest losses concerning their individual inclusiveness. Under qualified majority rule Member States with 10 votes increase their relative power to 75 percent, but even Spain with eight votes almost doubles its relative power share. Compared to unanimity, however, qualified majority voting has the highest variance in changes of absolute inclusiveness, since the absolute inclusiveness of large Member States only decreases by 13.7 percent, whereas Luxembourg loses about 42 percent of its absolute inclusiveness. Smaller Member States are subjected to the least power losses under double qualified majority voting, in either absolute or relative terms.

According to the actual provisions for $\mathrm{CM}$ decision rules, Member States expect no legislative gains from altering the decision rule in many policy domains, since they have not changed the provision for unanimity (König, 1996: 559). Qualified majority rules are primarily applied to legislation on the internal market, agriculture and the free movement of goods. In these domains, Member States expect gains with asymmetric distribution by increasing the potential for EU policy change. Moreover, the 'opt-out' clause of the United Kingdom and Denmark in social policy and the ongoing debate on monetary union herald new tendencies in the choice of decision rules. Both provisions indicate that the consensus precondition will be relaxed for future Treaty reforms.

\section{REFERENCES}

Banzhaf, John F. (1965) 'Weighted Voting Doesn’t Work: A Mathematical Analysis', Rutgers Law Review 19: 317-43.

Barry, Brian (1989) Democracy and Power. Oxford: Clarendon Press. 
Black, Duncan (1958) The Theory of Committees and Elections. Cambridge: Cambridge University Press.

Brams, Steven J. (1975) Game Theory and Politics. New York: Free Press.

Brams, Steven J. and Paul Affuso (1985) 'New Paradoxes of Voting Power on the EC Council of Ministers', Electoral Studies 4: 135-9.

Bräuninger, Thomas (1996) Die Modellierung von Entscheidungsverfahren internationaler Organisationen am Beispiel der Meeresbodenbehörde. Teilnahme-, Mitwirkungs- und Durchsetzungschancen in einem institutionalisierten Regime. Mannheim: Zulassungsarbeit.

Brückner, Matthias and Torsten Peters (1996) 'Further Evidence on EU Voting Power', Journal of Theoretical Politics 8: 415-19.

Buchanan, James M. and Gordon Tullock (1962) The Calculus of Consent: Logical Foundations of Constitutional Democracy. Ann Arbor: University of Michigan Press.

Bueno de Mesquita, Bruce, David Newman and Alvin Rabushka (1996) Red Flag Over Hong Kong. Chatham, NJ: Chatham House.

Coleman, James S. (1971) Control of Collectivities and the Power of a Collectivity to Act, in Bernhardt Lieberman (ed.), Social Choice, pp. 269-99. New York: Gordon \& Breach.

Dowding, Keith M. (1991) Rational Choice and Political Power. Aldershot: Edward Elgar.

Garrett, Geoffrey (1992) 'International Cooperation and Institutional Choice', International Organization 46: 533-60.

Garrett, Geoffrey (1993) 'The Politics of Maastricht', Economics and Politics 5: 105-23.

Garrett, Geoffrey and George Tsebelis (1996) 'An Institutional Critique of Intergovernmentalism', International Organization 50: 269-99.

Garrett, Geoffrey, Iain McLean and Moshé Machover (1995) 'Power, Power Indices and Blocking Power: A Comment on Johnston', British Journal of Political Science 25: 563-8.

Hosli, Madeleine O. (1993) 'Admission of European Free Trade Association States to the European Community: Effects on Voting Power in the European Community Council of Ministers', International Organization 47: 629-43.

Hosli, Madeleine O. (1996) 'Coalitions and Power: Effects of Qualified Majority Voting in the Council of the European Union', Journal of Common Market Studies 34: 255-73.

Johnston, Ronald J. (1995) 'The Conflict over Qualified Majority Voting in the European Union Council of Ministers: An Analysis of the UK Negotiating Stance Using Power Indices', British Journal of Political Science 25: 245-88.

Kapteyn, Paul and Pieter Verloren van Themaat (1990) Introduction to the Law of the European Communities, 2nd edn. Deventer: Kluwer.

König, Thomas (1996) 'The Constitutional Development of European Integration', Journal of Theoretical Politics 8: 553-9.

König, Thomas (1997) Europa auf dem Weg zum Mehrheitssystem. Gründe und Konsequenzen nationaler und parlamentarischer Integration. Opladen: Westdeutscher Verlag.

König, Thomas and Thomas Bräuninger (1996) 'Power and Political Coordination in American and German Multi-chamber Legislation', Journal of Theoretical Politics 8:331-60.

König, Thomas and Thomas Bräuninger (1997) The Constitutional Choice of Rules. An Application of the Absolute and Relative Power Concepts to European Legislation. MZES Working Paper/ABII No. 17. Mannheim: Mannheim Centre for European Social Research.

Krasner, Stephen D. (1991) 'Global Communications and National Power. Life on the Pareto Frontier', World Politics 43: 336-66.

Lane, Jan-Erik, Reinert Mæland and Sven Berg (1995) 'The EU Parliament: Seats, States and Political Parties', Journal of Theoretical Politics 7: 395-400.

Lange, Peter (1993) 'The Maastricht Social Protocol: Why did they do it?', Politics and Society 21: 5-36.

Ludlow, Peter (1991) 'The European Commission', in Robert O. Keohane and Stanley 
Hoffman (eds) The New European Community: Decisionmaking and Institutional Change, pp. 85-132. Boulder, CO: Westview.

Moravcsik, Andrew (1991) 'Negotiating the Single European Act: National Interests and Conventional Statecraft in the European Community', in Robert O. Keohane and Stanley Hoffmann (eds) The New European Community: Decisionmaking and Institutional Change, pp. 41-84. Boulder, CO: Westview.

Moravcsik, Andrew (1993) 'Preferences and Power in the European Community: A Liberal Intergovernmental Approach', Journal of Common Market Studies 31: 473-524.

Nugent, Neill (1994) The Government and Politics of the European Union, 3rd edn. Basingstoke: Macmillan.

Rae, Douglas W. (1969) 'Decision-rules and Individual Values in Constitutional Choice', American Political Science Review 63: 40-56.

Schneider, Gerald (1995) 'The Limits of Self-Reform: Institution-Building in the European Union', European Journal of International Relations 1: 59-86.

Shapley, Lloyd S. (1962) 'Simple Games: An Outline of the Descriptive Theory', Behavioral Science 7: 59-66.

Shapley, Lloyd S. and Martin Shubik (1954) 'A Method for Evaluating the Distribution of Power in a Committee System', American Political Science Review 48: 787-92.

Shelley, Fred M. (1986) 'Voting Power in Municipal Annexation Elections', Quality and Quantity 120: 257-60.

Shepsle, Kenneth A. and Barry R. Weingast (1987) 'The Institutional Foundations of Committee Power', American Political Science Review 81: 85-104.

Straffin, Philip D., Jr (1977) 'Homogeneity, Independence, and Power Indices', Public Choice 30: $107-18$.

Tsebelis, George (1990) Nested Games. Rational Choice in Comparative Politics. Berkeley: University of California Press.

Tsebelis, George (1994) 'The Power of the European Parliament as a Conditional Agenda Setter', American Political Science Review 88: 128-42.

Tsebelis, George (1996) 'More on the European Parliament as a Conditional Agenda Setter: Response to Moser', American Political Science Review 90: 839-44.

Tsebelis, George and Geoffrey Garrett (1996) 'Agenda Setting Power, Power Indices and Decision Making in the European Union', International Review of Law and Economics 16: $345-61$.

Wallace, Helen (1985) 'Negotiations and Coalition Formation in the European Community', Government and Opposition 20: 453-72.

Widgrén, Mika (1994) 'Voting Power in the EC Decision-Making and the Consequences of Two Different Enlargements', European Economic Review 38: 1153-70.

THOMAS KÖNIG is Privatdozent in Political Science and Heisenberg Fellow of the Deutsche Forschungsgemeinschaft. His research topics are comparative politics, in particular the comparative study of legislative decision-making, and the institutional analysis of international relations, either the choice of or within rules. He is co-editor, with Elmar Rieger and Hermann Schmitt, of the Mannheimer Jahrbuch zur Europäischen Sozialforschung (Campus, 1996-7) and he recently published Europa auf dem Weg zum Mehrheitssystem (Westdeutscher Verlag, 1997). ADDRESS: Mannheim Centre for European Social Research, University of Mannheim, 7, 1, 68131 Mannheim, Germany.

[email: Thomas.Koenig@mzes.uni-mannheim.de] 
THOMAS BRÄUNINGER is research fellow of the Landesgraduiertenförderung Baden-Württemberg. He is currently working on the constitutional choice of rules in international negotiation systems. ADDRESS: see above. [email: Thomas.Braeuninger@mzes.uni-mannheim.de] 